\title{
PENGARUH TEMPERATUR PADA PROSES PERLAKUAN PANAS BAJA TAHAN KARAT MARTENSITIK AISI 431 TERHADAP LAJU KOROSI DAN STRUKTUR MIKRO
}

\author{
Eddy Gunawan ${ }^{1}$ \\ 1Teknik Mesin, Fakultas Teknik \\ Universitas Maarif Hasyim Latif, Sidoarjo, Indonesia \\ e-mail : gunawaneddy56@yahoo.com
}

Diterima: 29 Maret 2017. Disetujui : 22 Mei 2017. Dipublikasikan : 1 Juni 2017

(C)2017 -TESJ Fakultas Teknik Universitas Maarif Hasyim Latif. Ini adalah artikel dengan akses terbuka di bawah lisensi CC BY 4.0 (https://creativecommons.org/licenses/by/4.0/)

\begin{abstract}
ABSTRAK
Suatu permukaan logam yang berinteraksi langsung dengan lingkungan korosif dengan adanya keadaan ketidakseragaman akan terjadi perbedaan potensial efektif lokal, sehubunan dengan itu makan akan terjadi korosi pada daerah yang lebih anodic daripada permukaan lain disebabkan oleh perlakuan yang dilakukan pada material tersebut, misalnya adalah proses heat treatment.

Dalam penelitian ini obyek yang diteliti adalah baja tahan karat martensitic stainless steel AISI dengan kadar krom 17\%, kadar karbon 0,20\%, kadar nikel 1,6\%. Pada penelitian kali ini akan dilakukan suatu penelitian terhadap pengaruh variasi temperatur pemanasan pada proses heat treatment terhadap laju korosi. Proses heat treatment disini adalah menggunakan temperatur pemanasan : $750^{\circ} \mathrm{C}, 850^{\circ} \mathrm{C}, 950^{\circ} \mathrm{C}$, ditahan 30 menit dan di quenching dengan media pendingin air. Dari proses heat treatment tersebut akan dilakukan pengujian kekerasan strukturmikro dan uji laju korosi, dimana metode yang digunakan adalah metode immerse (media korosif HCL).

Dari hasil pengujian tersebut di atas didapatkan hasil sebagai berikut : baja tanpa laku panas mengalami laju korosi sebesar $51,8 \mathrm{mpy}$, untuk baja mengalami laku panas $750^{\circ} \mathrm{C}$ dengan holding time 30 menit. Laju korosi specimen 1 adalah 50 mpy, specimen 2 adalah 30 mpy, specimen 3 adalah 76 mpy, specimen 4 adalah $68 \mathrm{mpy}$, specimen 5 adalah $67 \mathrm{mpy}$. Untuk laku panas $850^{\circ} \mathrm{C}$, laju korosi specimen 1 adalah $43 \mathrm{mpy}$, specimen 2 adalah 61 mpy, specimen 3 adalah 46 mpy, specimen 4 adalah 29 mpy, specimen 5 adalah 27 mpy. Untuk laku panas $950^{\circ} \mathrm{C}$, laju korosi specimen 1 adalah $82 \mathrm{mpy}$, specimen 2 adalah 84 mpy, specimen 3 adalah 78 mpy, specimen 4 adalah 75 mpy, specimen 5 adalah 77 mpy.
\end{abstract}

Kata Kunci : temperatur, laju korosi, laju pendinginan

\section{PENDAHULUAN}

Di dalam perkembangan industri, terutama dalam bidang permesinan metalurgi memegang peranan penting dalam pemilihan logam yang memiliki sifat-sifat mekanik maupun fisik yang sesuai dengan tuntutan produksi. Maka sikap perancang desaign dan ahli metalurgi harus mampu untuk menentukan pilihannya terhadap logam yang memperbaiki sifat-sifat logam diantaranya adalah sifat tahan korosi yang baik.

Adapun interaksi antara material dan lingkungan yang menyebabkan penurunan kualitas dan keterbatasan umur pemakaian adalah korosi. Korosi merupakan salah satu factor yang berbahaya bagi material, khususnya logam. Contohnya kebocoran pipa akibat serangan korosi.

Untuk menanggulangi serangan korosi tersebut maka dilakukan penelitian untuk menyelidiki hubungan antara struktur mikro de- ngan laju korosi, diharapkan nantinya didapatkan suatu metode baru untuk mempertinggi corrosion resistance suatu material dengan memperbaiki bentuk, ukuran, jenis, dan struktur mikronya.

\section{METODE PENELITIAN}

Metode yang dilaksanakan dalam penelitian ini adalah :

1. Bahan yang akan diuji adalah baja tahan karat AISI 431 dengan spesifikasi yang tercantum dalam katalog.

2. Laku panas pada baja tahan karat AISI 431 ini adalah baja yang dipanaskan dengan variasi temperatur $750^{\circ} \mathrm{C}, 850^{\circ} \mathrm{C}, 950^{\circ} \mathrm{C}$ dengan holding time 30 menit.

3. Setelah dilakukan laku panas, baja tahan karat AISI 431 dilakukan Uji Jominy Hardenability Test sesuai standar ASTM A 276 dengan dimensi sebagai berikut dengan $\varnothing 25 \mathrm{~mm}$ dengan panjang $100 \mathrm{~mm}$, media pendingin air. 
4. Specimen diukur berat awal, luas penampang,density

5. Kemudian specimen jominy ini dipotong secara melintang dengan ukuran $1 / 4$ inchi, pada bagian ujung, tengah, dan bagian yang dekat dengan quench sesuai dengan SNI General Corrosion Test.

6. Untuk pengujian laju korosi ini media korosif menggunakan asam pekat dalam hal ini HCL. Pengujian korosi dilakukan diremdam menggunakan HCL minimal selama 24 jam.

7. Setelah direndam minimal 24 jam, kemudian ditimbang ulang, kemudian dibandingkan dengan berat sebelum pengujian (weight loss),

8. Kemudian dilakukan uji metallografi untuk mengetahui jenis korosi yang timbul pada baja tahan karat AISI 431.

9. Hasil dari analisis data dirangkum.

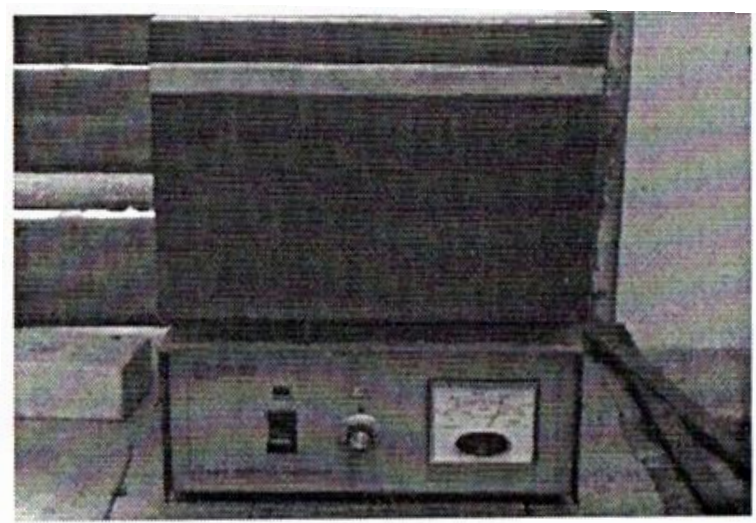

Gambar 1. Dapur pemanasan

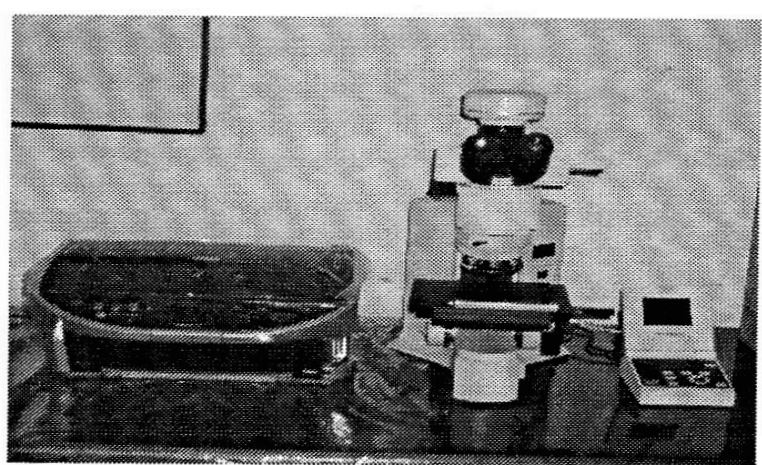

Gambar 2. Mikroskop dan kamera digital

\section{Dapur pemanasan}

Peralatan ini digunakan untuk perlakuan panas dan holding time pada temperatur serta waktu penahanan yang ditentukan, pada penelitian ini temperatur yang digunakan adalah $750^{\circ} \mathrm{C}$, $850^{\circ} \mathrm{C}, 950^{\circ} \mathrm{C}$, dan waktu penahanan 30 menit.

Pengoperasian Dapur/furnace :

1. Tancapkan stop kontak ke PLN

2. Tekan tombol power on/off

3. Putar tombol cycle, atur temperatur sampai batas yang ditentukan.
4. Masukkan benda kerja.

5. Atur holding time dengan menurut tombol cycle sesuai batas yang ditentukan.

6. Keluarkan benda kerja

7. Kembalikan tombol cycle ke posisi off

8. Lepaskan stop kontak

\section{Peralatan grinding dan polishing}

Peralatan ini bertujuan untuk membuat permukaan specimen rata, sehingga dapat diamati struktur mikro nya maupun struktur makro untuk pengamatan. Proses ini berlangsung secara bertahap dengan tingkat kekerasan yang tinggi sampai rendah, proses grinding dengan menggunakan kertas gosok dengan tingkat grid tertentu dengan dialiri air sampai specimen tersebut halus. Sedangkan proses polishing dengan menggunakan kain wol dan pasta HCL sampai specimen menjadi lebih halus.

\section{Peralatan pengamatan struktur mikro}

Peralatan struktur mikro ini dilakukan di laboratorium metallograpy, dimana peralatan yang digunakan antara lain :

1. Mikroskop dan kamera digital

2. Satu unit komputer

Gambar yang diperoleh dari mikroskop dikirim ke digital still recorder melalui kamera dan gambar yang sudah direkam kemudian disimpan oleh komputer dalam bentuk file. Dengan peralatan ini dapat dilakukan pengamatan dengan pembesaran 100x.

\section{Pelaksanaan pekerjaan}

Pelaksanaan percobaan yang dilakukan dalam penelitian ini dari awal mulai persiapan specimen uji, sampai pengambilan data yang dibutuhkan meliputi beberapa langkah. Adapun langkah yang ditempuh tersebut adalah :

1. Mempersiapkan specimen sesuai standart jominy test.

2. Melakukan uji jominy test.

3. Melakukan proses grinding atau menggosok sebagian permukaan yang akan diuji kekerasannya.

4. Melakukan pertimbangan sebelum dan sesudah uji korosi supaya mendapat data weight loss.

5. Melakukan pengambilan data laju korosi.

6. Machining.

7. Melakukan proses polishing.

8. Pengambilan data gambar struktur mikro.

Untuk langkah-langkah percobaan, yaitu :

1. Dapur pemanas dipanaskan awal hingga mencapai temperatur $750^{\circ} \mathrm{C}$.

2. Setelah mencapai temperatur $750^{\circ} \mathrm{C}$, benda uji baja tahan karat AISI 431 dimasukkan ke dalam dapur pemanas. Kemudian dilakukan 
penahanan pada temperatur tersebut selama 30 menit untuk mendapatkan benda uji pertama.

3. Kemudian benda uji pertama yang telah mendapatkan holding time 30 menit dikeluarkan dari dapur pemanas untuk dilakukan jominy tes dengan media air selama 14 menit

4. Benda uji yang telah dimasukkan, maka temperatur dinaikkan hingga temperatur $850^{\circ} \mathrm{C}$ secara bertahap.

5. Setelah mencapai temperatur $850^{\circ} \mathrm{C}$ dilakukan penahanan pada temperatur tersebut selama 30 menit, untuk mendapatkan benda uji kedua.

6. Kemudian benda uji kedua yang telah mendapatkan holding time 30 menit dikeluarkan dari dapur untuk dilakukan jominy test dengan media air selama 14 menit.

7. Untuk benda uji ketiga, benda uji yang telah dimasukkan maka temperatur dinaikkan lagi hingga temperatur mencapai $950^{\circ} \mathrm{C}$ secara bertahap, dilakukan seperti langkah di atas.

8. Setelah mencapai temperatur $950^{\circ} \mathrm{C}$ dilakukan penahanan pada temperatur tersebut selama 30 menit, untuk mendapatkan benda uji ketiga.

9. Kemudian benda uji ketiga yang telah mendapatkan holding time 30 menit dikeluarkan dari dapur untuk dilakukan jominy test dengan media air selama 14 menit.

10. Setelah semua benda uji mengalami jominy test, maka benda uji yang telah mencapai suhu kamar, akan dilakukan uji kekerasan metode rockwell $\mathrm{C}$ pada bagian permukaan dengan jarak tertentu untuk mengetahui kekerasan setelah laku panas.

11.Specimen dipotong sesuai ukuran general corrosion test, dibersihkan untuk dilakukan pengujian berikutnya.

12. Uji metallography dilakukan untuk mengetahui struktur mikro martensitik steel yang telah dilakukan laku panas sebelum pengujian korosi.

13. Kemudian dilakukanpenimbangan awal untuk mengetahui berat awal sebelum dilakukan pengujian korosi.

14. Kemudian dilakukan pengujian korosi dengan menggunakan media korosif yaitu HCL.

15. Specimen korosi direndam dalam larutan HCL dengan waktu selama 24 jam.

16. Setelah direndam ke dalam larutan HCL selama 24 jam, specimen dibilas dengan air.

17. Kemudian specimen dibersihkan dari karat yang timbul di permukaan specimen korosi, menggunakan kertas gosok dengan campuran pasta sebagai pembersih lalu dibilas dengan air.

18. Pembilasan telah dilakukan kemudian specimen dilakukan uji metallography untuk mengetahui perbandingan gambar struktur mikro sebelum dan sesudah dilakukan general corrosion test.

19. Setelah dilakukan pengujian metallography, kemudian specimen ditimbang kembali untuk mengetahui berat sebelum dan sesudah general corrosion test sehingga mendapatkan weight loss dari specimen tersebut.

20.Setelah pengujian dilakukan, kemudian dianalisis data nya.

\section{Baja Tahan Karat}

Baja tahan karat termasuk dalam grup besi paduan tingkat resistensi tinggi terhadap serangan kimia atau sifat tahan karat. Banyak diantara baja ini yang digolongkan secara metalurgi menjadi baja tahan karat austenite baja tahan karat ferrit, baja tahan karat martensit dan baja tahan karat tipe presipitasi.

Sifat tahan karat ini biasanya didapat dengan cara dipadukan atau dicampur dengan minimal 11 $\%$ kromium. Semakin tinggi paduan kromium dan penambahan nikel, dan beberapa elemen lain akan membuat sifat tahan karat dari stainless steel semakin baik.

Dengan penambahan kromium ini akan menyebabkan baja bersifat tahan karat, karena lapisan chrom menyebabkan permukaan pasif atau stabil, keadaan ini didapat karena chrom lebih mudah teroksidasi. Besar kecilnya kandungan chrom sangat berpengaruh sekali terhadap ketahanan korosi pada baja. Oleh karena itu, baja tahan karat harus mengandung unsur chromium tidak kurang dari 10\% serta kadar karbon yang sesuai agar sifat mekanik cukup baik.

Adapun dengan penambahan unsur nikel juga akan menyebabkan baja bersifat tahan karat karena unsur nikel akan mengurangi berat yang hilang akibat korosi dalam asam dan memperbaiki ketahanan korosi. Jadi baja tahan karat adalah baja paduan yang memanfaatkan keefektifan unsur $\mathrm{Cr}$ dan $\mathrm{Ni}$, baja tahan karat sebenarnya adalah baja paduan dengan kadar paduan tinggi (high alloy steel) dengan sifat istemewa yaitu tahan terhadap korosi dan temperatur tinggi. Sifat tahan korosinya di dapat dari lapisan oksida (terutama krom) yang sangat stabil yang melekat pada permukaan dan melindungi baja terhadap lingkungan yang korosif.

Dalam deret elektrokimia chromium merupakan logam yang kurang mulia, jika dibandingkan dengan besi (Fe). Oleh karena itu baja yang mengandung unsur paduan chromium akan teroiksidasi (dikenal dengan peristiwa korosi), sehingga secara teoritis akan mengalami kerusakan dengan cepat. Tetapi tidak demikian dengan kenyataannya, pada mulanya baja itu mengalami reaksi oksidasi chromium pada permukaan baja. Lapisan ini sangat kuat sehingga udara sekitar tidak mampu menembus lapisan yang mengakibatkan kontak langsung antara oksigen dan chromium tidak terjadi lagi. Dengan sendirinya reaksi dengan oksigen akan terhenti. Lapisan oksida chrom ini yang melindungi baja di bawahnya terhadap serangan korosi. 
Mengenai kodefikasi baja tahan karat sesuai standart AISI, maka baja tahan karat menggunakan tiga angka. Angka pertama menunjukkan group, sedangkan angka yang kedua dan ketiga tidak banyak artinya (hanya menunjukkan modefikasi paduannya). Seperti baja tahan karat AISI 431 yang akan dibahas. Seri 431 termasuk group yang berarti chromium, hardenable, magnetic, dapat dikeraskan, dapat cold-work dengan mudah serta machinability cukup baik.

Bila kadar karbon ditambah, maka terjadi ferit delta dan austenite, sehingga bila di uench akan terbentuk martensit meskipun belum seluruhnya martensit, karena struktur yang dihasilkan terdiri dari ferit dan produk transformasi austenite.

Bila kadar karbon dinaikkan lebih tinggi, diperoleh austenite dan karbida, setelah di quench akan menghasilkan kekerasan penuh dengan struktur terdiri dari martensit, transformasi austenite dan partikel karbida yang tak terlarut pada saat pemanasan sehingga tidak bertransformasi (tetap berupa karbida).

Dengan penambahan nickel (austenite stabilizer) yang banyak maka daerah austenite akan turun dan dapat mencapai temperatur kamar, sehingga struktur yang dihasilkan terdiri dari austenite (tidak dapat dikeraskan) meskipun diquenching.

Stainless steel merupakan baja paduan, dimana terdapat unsur-unsur paduan didalamnya yang mempunyai keunggulan masing-masing, diantaranya sebagai berikut :

1. Penambahan Molibdenum (Mo) bertujuan untuk memperbaiki ketahanan korosi.

2. Penambahan unsur penstabil karbida (titanium dan niobium) bertujuan menekan korosi batas butir pada material yang mengalami proses sensitasi.

3. Penambahan kromium (Cr) bertujuan meningkatkan ketahanan korosi dengan membentuk lapisan oksida dan ketahanan terhadap oksidasi temperatur tinggi.

4. Penambahan nikel (Ni) bertujuan untuk meningkatkan ketahanan korosi dalam media pengkorosi netral atau lemah.

Dalam suatu proses laku panas, setelah pemanasan mencapai temperatur yang telah ditentukan dan diberi holding time secukupnya maka dilakukan pendinginan dengan laju tertentu, seperti Gambar 3. Struktur mikro yang terjadi setelah pendinginan akan tergantung pada laju pendinginan.

Letak kurva transformasi dalam suatu I-T diagram dipengaruhi oleh dua factor utama yaitu komposisi kimia dari baja dan ukuran butir Kristal austeni. Pada umumnya makin tinggi kadar karbon dan kadar unsur paduan maka makin besar ukuran butir Kristal austenite, maka letak kurva transformasi dalam suatu diagram transformasi akan makin ke kanan.

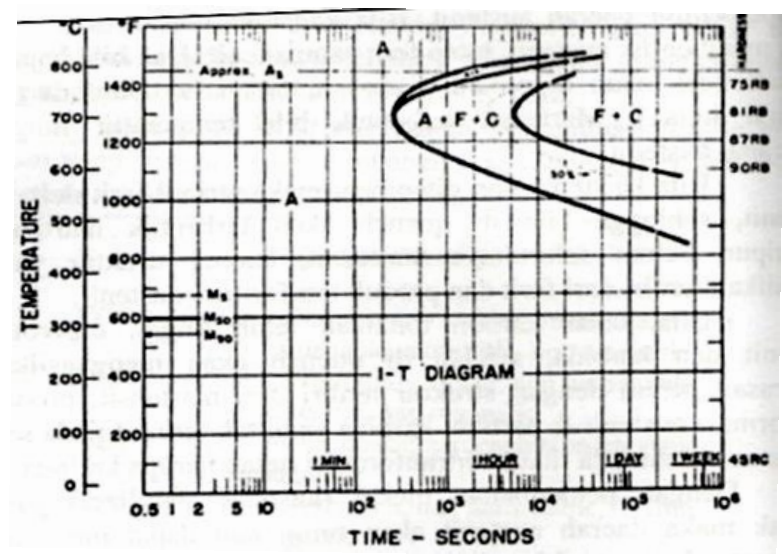

Gambar 3. Diagram baja martensit AISI 431

Dengan demikian CCR makin lambat, makin mudah melakukan pendinginan untuk membentuk martensit sehingga baja mudah untuk diperoleh sifat yang keras.

Dari perubahan di atas menurut struktur mikro nya, maka baja tahan karat dapat dibagi menjadi tiga kelompok, yaitu :

\section{1) Ferritik Stainless Steel}

Ferritic stainless steel tersusun atas struktur mikro ferrit alfa, dengan lattice BCC. Kandungan chromium berkisar antara 14,5\%-27\%. Pada gambar 2.3 dapat dilihat bahwa kandunan chromium kira-kira $12 \%$ hanya fase ferrit yang terjadi hingga temperatur kamar Kestabilan ferrit hingga temperatur kamar tersebut mengakibatkan feeritic stainless steel tidak dapat dikeraskan dengan proses perlakuan panas. Satu-satunya proses laku panas yang dapat dilakukan adalah annealing, yang biasanya dimaksudkan untuk menghilangkan tegangan akibat pengelasan. Chromium merupakan elemen pembentuk ferrit. Semakin banyak kandungan chromium dalam paduan, maka fase ferrit akan makin stabil dan selain itu chromium dapat mempersempit daerah austenite.

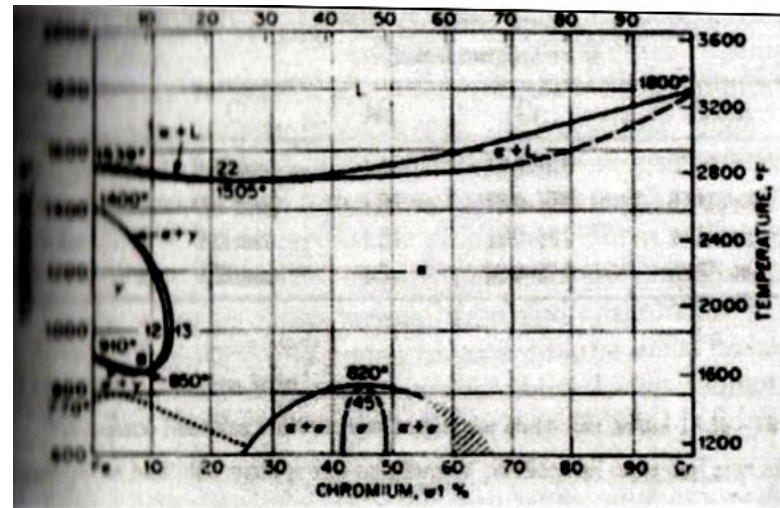

Gambar 4. Diagram keseimbangan besi-kromium 
2) Baja tahan karat martensitik

Martensit bukanlah suatu struktur yang stabil, tapi merupakan suatu struktur transisi antara austenite yang tidak stabil pada temperatur kamar dengan campuran feerit dan cementit yang stabil. Baja tahan karat martensitik mengandung unsur chromium antara 15\%-18\% dan merupakan hasil dari suatu proses transformasi pendinginan cepat dari austenitic pada temperatur tinggi. Baja tahan karat martensitik ini dikembangkan untuk mendapatkan paduan yang mempunyai sifat tahan korosi dan dapat dikeraskan dengan proses laku panas dengan menambahkan elemen karbon pada system biner $\mathrm{Fe}-\mathrm{Cr}$ yang akan menghasilkan paduan yang dapat di quench.

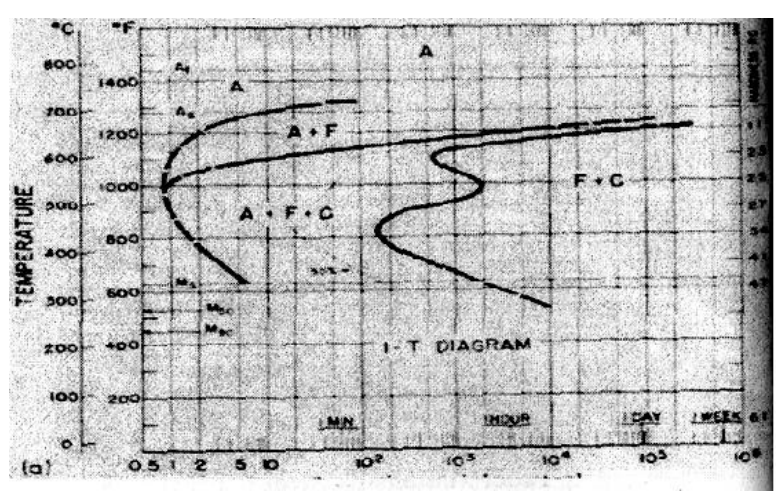

Gambar 5. Diagram perlakuan panas pada baja AISI 431

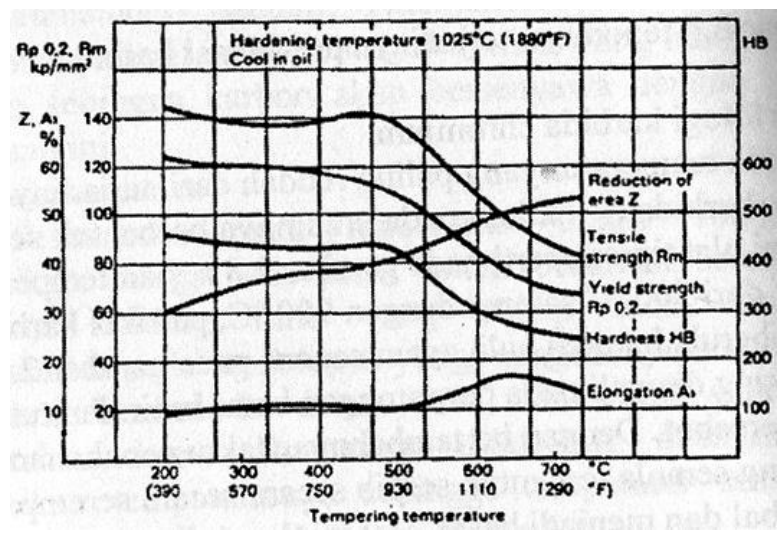

Gambar 6. Grafik Heat Treatment Martensitic Steel AISI 431

Baja tahan karat martensitik AISI 431 adalah jenis baja paduan rendah yang mempunyai struktur hampir sama dengan ferritic steel. Apabila ditambahkan unsur karbon dapat menjadi keras dan kekuatannya bertambah apabila mengalami heat treatment.

3) Austenitic Stainless Steel

Austenitic Stainless Steel pada umumnya adalah paduan Fe-Cr-Ni dan cukup dikenal dengan 300 series, bersifat non magnetic, pada temperatur kamar mempunyai fase austenitic yang dominan, dimana unsur Ni sebesar 3,5\%-37\% . Bertujuan untuk menstabiolkan fase austenite khusus akibat proses pendinginan dari temperatur tinggi.

\section{Presipitasi karbida}

Dalam baja, karbon merupakan elemen yang harus diperhitungkan. Semakin tinggi temperatur, daya kelarutan karbon semakin meningkat sehingga jika karbon berkaitan dengan logam, maka akan terbentuk karbida. Kekerasan dan kekuatan martensit meningkat dengan bertambahnya kandungan karbon. Peningkatan kekuatan karbon karena terjadinya presipitasi karbida.

\section{Heat Treatment}

Dalam penelitian ini menggunakan variasi temperatur $750^{\circ} \mathrm{C}, 850^{\circ} \mathrm{C}, 950^{\circ} \mathrm{C}$, dan dengan holding time 30 menit. Pendinginan menggunakan media air.

\section{Jominy hardenabilitytest}

Dalam pengujian ini, benda uji yang digunakan adalah batang silindris diameter $25 \mathrm{~mm}$ panjang $100 \mathrm{~mm}$ (lebih lengkapnya pada gambar 2.9. Setelah benda uji dipanaskan dalam dapur pemanas, maka benda uji dikeluarkan dan ditempatkan ke suatu pemegang (frame). Kemudian ujung benda uji disemprot dengan pancaran air (sebagai media pendinginnya) dari sebuah nozzle berdiameter $12,5 \mathrm{~mm}$. Sedangkan jarak antara ujung benda uji dengan nozzle 12,5 $\mathrm{mm}$, tinggi pancaran air $65 \mathrm{~mm}$.

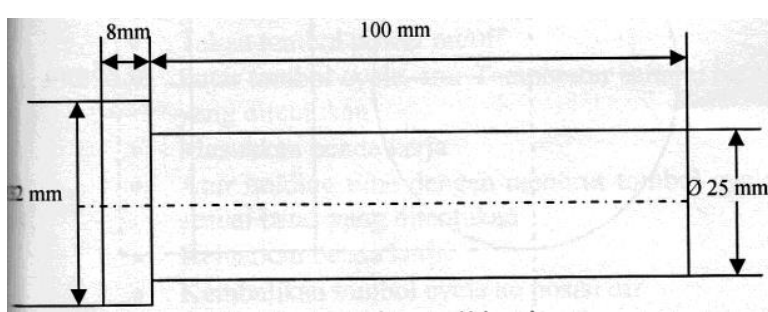

Gambar 7. Spesimen uji jominy test
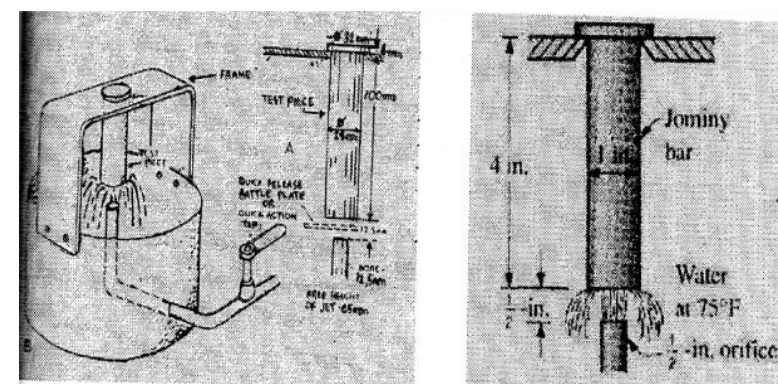

Gambar 8. Jominy hardenabilitytest

Setelah mengalami pengujian Jominy Hardenability Test, maka benda uji dibiarkan dingin dan kemudian dilakukan pengujian berikutnya yaitu uji kekerasan metode Rockwell C. Kekerasan yang diambil pada sepanjang sisi permukaan batang silindris. 
Benda uji mempunyai komposisi kimia tertentu akan mengalami laju pendinginan yang sama akan terbentuk struktur dan kekerasan tertentu. Maka dengan jominy hardenability test ini, benda uji akan dapat ditentukan berapa kekerasan yang terjadi pada titik-titik tertentu.

Sehingga dari pengujian ini dapat diketahui distribusi kekerasan pada benda uji. Kekerasan maksimum suatu logam pada dasarnya tergantung pada kadar karbon, sedankan hardenability tergantung pada komposisi kimia (unsur paduan dan kadar karbon) serta batas butirnya.

\section{Korosi}

Pada peristiwa korosi, logam dikonversikan menjadi compoundnya dan bila hal ini terjadi logam akan mengalami : permukaan rusak, kehilangan streght, ductility dan sifat-sifatnya yang lain menurun. Setiap tahunnya banyak biaya yang dikeluarkan akibat korosi ini. Kegagalan-kegagalan yang mahal harganya seperti dengan rusaknya sebagian kecil komponen akan mengakibatkan capital installation yang besar dan tidak berguna. Logam mempunyai energy bebas yang sehingga logam ini cenderung melepaskan free energinya untuk mencapai tingkat energy yang terendah.

Korosi dapat di definisikan sebagai satu bentuk kerusakan pada sebuah logam, disebabkan adanya interaksi dan lingkungannya. Bentuk kerusakan logam karena akibat langsung proses mekanis ataupun fisis tidak dapat dikatakan sebagai bentuk kerusakan logam biasa.

Pada umumnya serangan korosi terjadi pada permukaan logam yang berinteraksi langsung dengan lingkungan korosi sehingga secara visual dapat dilihat dengan jelas perubahan-perubahan baik warna maupun bentuk pada permukaan logam tersebut. Selain itu korosi dapat juga dikatakan sebagai kebalikan dari proses extractive metallography artinya reaksi korosi yang terjadi adalah menuju ke dalam bentuk keseimbangan alamiah dari logam. Dari definisi tersebut maka dapat disimpulkan bahwa korosi adalah reaksi kimia atau elektrokima antara logam dengan lingkungan yang mengakibatkan penurunan sifat logam.

Korosi secara kimia adalah korosi yang terjadidengan reaksi kimia murni. Pada proses ini terjadi tanpa ikut sertanya electron. Sedangkan korosi secara elektrokimia terjadi bila reaksinya berlangsung dalam suatu elektrolit, pada proses ini terjadi perpindahan electron dari anoda ke katoda. Jenis-jenis korosi :

1. Korosi lubang (Pitting Corrosion), merupakan bentuk korosi local berbentuk titik-titik yang sangat membahayakan karena akan menyebabkan lubang pada logam yang secara selektf menyerang bagian permukaan logam yang : a) Selaput pelindungnya tergores atau retak akibat perlakuan mekanik.

b) Mempunyai tonjolan akibat dislokasi yang disebabkan oleh tegangan tarik yang dialami

2. Korosi celah, korosi ini sering terjadi antara celah dengan daerah sekitarnya yang tertutup pada permukaan logam. Korosi ini ditimbulkan olehadanya larutan yang stagnant pada celah, seperti celah antara bolt dan rivet.

3. Korosi fatique, korosi sifatnya hanya mempercepat laju korosi yang disebabkan adanya cycles stress condition.

Untuk mengatasi korosi ada beberapa cara, yaitu :

1. Dengan memperlambat laju elektron.

2. Meminimalkan kontak oksigen.

3. Memilih bahan yang lebih tahan terhadap serangan korosi.

Faktor-faktor yang menyebabkan terjadinya korosi:

1. Faktor dalam (logam yang bersangkutan) :

a. Kandungan unsur-unsur : Kandungan unsurunsur $\mathrm{Cr}$ dan $\mathrm{Ni}$ dalam jumlah yang besar mempunyai daya tahan korosi tinggi.

b. Sifat-sifat mekanik : Kekerasan dari logam mempengaruhi ketahanan terhadap korosi erosi.

c. Struktur mikro logam : Struktur dari logam mempengaruhi korosi yang terjadi

d. Kondisi Permukaan : Semakin halus permukaan logam cenderung ketahanan korosi semakin tinggi.

2. Faktor luar (Faktor lingkungan) :

a. Keasaman larutan : Ion hidrogen memegang peranan dalam kebanyakan reaksi korosi secara elektrokimia, keasaman larutan yang dinyatakan dalam konsentrasi ion $(\mathrm{PH})$ merupakan faktor yang penting. Logam berada dalam lingkungan asam (PH rendah) akan lebih cepat terkorosi dan sebaliknya.

b. Oksigen : Pada logam-logam tertentu seperti baja karbon, bila berada dalam lingkungan atau media yang mengandung oksigen, maka laju korosi yang terjadi semakin tinggi. Tetapi sebaliknya pada logam baja tahan karat, adanya oksigen akan meningkatkan ketahanan korosinya karena terbentuknya lapisan oksida khrom sebagai pelapisan pelindung.

c. Pengaruh tekanan mekanis : Adanya tekanan statik pada logam dalam lingkungan tertentu akan memacu untuk terjadinya korosi terganggu yang mengakibatkan penurunan ketahanan pada logam tersebut, sedangkan bila tegangan bersifat dinamik akan cenderung terjadi korosi kelelahan.

d. Kecepatan aliran/tumbukan : Kecepatan aliran dari media akan menyebabkan laju korosi, erosi naik, hal tersebut juga dipengaruhi oleh jenis, komposisi fluida dan adanya partikel-partikel padat dalam fluida tersebut. 
e. Temperatur : Adanya kenaikan temperatur akan memacu laju korosi dimana temperatur naik, energi pun semakin naik, sehingga reaksi

Untuk menghindari akibat serangan berbagai jenis korosi yang sangat merugikan tersebut diperlukan langkah-langkah pencegahan yang cukup mahal biayanya. Namun jika dibanding dengan biaya dan pengorbanan lain jika serangan korosi tidak dicegah atau dibatasi, maka kerugian akibat biaya pencegahan tersebut di atas menjadi hampir tidak bearti.

Ada beberapa prinsip pencegahan korosi yang penggunaanya disesuaikan dengan jenis peralatan, tepat, serta jenis lingkungan yang korosif. Adapun prinsip-prinsip pencegahan korosi tersebut adalah sebagai berikut:

1. Prinsip perbaikan lingkungan yang korosif.

2. Prinsip netralisasi zat koroden sedemikian rupa sehingga tidak berbahaya lagi.

3. Prinsip perlindungan permukaan dengan cara :
a. Pelapisan dengan cat (organic coating).
b. Pelapisan dengan metal coating, lining, overlay, dan cladding.
c. Pelapisan anorganic.
d. Pembalutan (wrapper)

4. Prinsip penggunaan bahan yang tahan terhadap jenis korosi tertentu.

5. Perlindungan katodic dan perlindungan anodic.

6. Penggunaan zat pelambat korosi (corrosion inhibitor).

Pendayagunaan keenam prinsip ini harus tepat agar mendapatkan hasil yang optimum baik ditinjau dari aspek ekonomi serta efeksitas perlindungannya. Demikian pula cara pendayagunaan prinsip perlindungan/pecegahan korosi harus benar-benar tepat sehingga dapat dihasilkan mutu perlindungan yang handal dan tahan lama.

Korosi tidak dapat dicegah namun bisa dikendalikan. Pengendalian korosi didasarkan pada beberapa metode yaitu :

1. Desain dan pemilihan material : Metode ini awal proteksi korosi karena merangsang sedemikian rupa sehingga laju korosi dapat dikendalikan dengan metode yang tepat:

a. Korosi merata, korosi ini dapat dihindari dengan pemilihan logam yang tepat sesuai dengan lingkungannya.

b. Korosi celah hindari dengan desain sambungan keling menggantikan sambungan las, hindari desain dengan sudut runing menghindari celah sempit dengan menutup dengan gasket yang solid.

c. Korosi galvanic, hindari desain pasangan logam yang berbeda jika tidak memungkinkan batasi keduanya dengan isolator atau pilih logam dengan harga potensial yang berdekatan dan hindari pasangan logam anoda kecil dan katoda yang luas. d. Korosi erosi, erosi kavitasi dengan desain perpiaan dengan memberikan permukaan yang halus sehingga pengolahan fluida dapat dihindari.

2. Pelapisan (coating) : Korosi elektrokimia terjadi apabila terdapat empat komponen yaitu : anoda katoda elektrolit dan konduktor metalik. Dengan menghilangkan salah satu komponen tersebut akan korosi terhambat.

3. Perubahan kondisi lingkungan : Media korosi di lingkungan logam media korosif dibagi menjadi 3 bentuk yang mungkin, yaitu berupa gas (oksigen, $\mathrm{H}_{2} \mathrm{~S}$ ), cairan (air larutan asam, dll) atau padatan (tanah, mineral,dll). Untuk lingkungan gas, pengendalian korosi dengan mengatur kelembapan relatif, menghilangkan pengotor. Untuk lingkungan cairan, menurunkan konsentrasi oksigen, mengatur suhu. Sedangkan di lingkungan padat pengendalian bisa dilakukan dengan pengendalian $\mathrm{PH}$.

4. Perubahan potensial logam : Metode pengendalian korosi yang paling populer dari aplikatif di industri adalah dengan merubah potensial logam dimana logam dikondisikan berada pada potensial aman.

\section{Pengujian korosi}

Model Pengkorosian yang direncanakan dalam penelitian ini yaitu dengan mencelupkan specimen yang telah dilakukan proses perlakuan panas dengan 3 macam variasi temperatur ke dalam larutan HCL selama 24 jam. Tiga macam variasi temperatur yaitu : (1) 5 specimen dengan temperatur $750^{\circ} \mathrm{C}$, (2) 5 specimen dengan temperatur $850^{\circ} \mathrm{C}$ dan (3) 5 specimen dengan temperatur $950^{\circ} \mathrm{C}$.

Setelah selama 24 jam (1 hari) logam baja dalam hal ini specimen uji AISI 431 dicelupkan ke dalam larutan kimia (HCL) sebagai media korosi akan mengalami korosi yang mengakibatkan berat logam specimen uji tersebut akan berkurang dari berat awal setelah 24 jam specimen uji tersebut dikeluarkan dari media korosi dan dilakukan pembersihan specimen serta dilakukan penimbangan.

\section{Metallography}

Pengamatan metallography didasarkan pada perbedaan intensitas sinar pantul permukaan logam yang masuk ke dalam mikroskop sehingga terjadi gambar berbeda (gelap, agak terang, terang). Apabila terhadap permukaan yang telah dihaluskan (polish) dicelupkan ke dalam suatu media kimia (etsa), maka permukaan logam tersebut akan dilarutkan.

Struktur mikro yang berbeda akan dilarutkan dengan kecepatan yang berbeda sehingga meninggalkan bebas permukaan dengan orientasi sudut yang berbeda pula. Dengan 
demikian apabila seberkas sinar dikenakan pada permukaan logam yang telah diuji maka sinar tersebut akan dipantulkan sesuai dengan orientasi sudut permukaan yang terkena.

\section{HASIL DAN PEMBAHASAN}

Sebelum dilakukan pengkorosian material baja hasil proses heat treatment, baja dibersihkan dengan kertas gosok lalu ditimbang berat awalnya $\left(\mathrm{W}_{0}\right)$, dan didapatkan nilainya sebagai berikut. Setelah dilakukan pengkorosian dengan cara mencelupkan material baja ke dalam larutan HCL. Pencelupan tersebut dilakukan selama 1 hari. Kemudian baja diambil lalu dibersihkan terlebih dahulu dengan air biasa lalu ditimban berat material baja tersebut $\left(\mathrm{W}_{\mathrm{a}}\right)$, dan didapat grafik pengaruh variasi temperatur pada baja AISI 431 terhadap berat yang hilang.

Beradasrkan grafik, dari data hasil pengukuran berat setelah dilakukan proses perlakuan panas dengan variasi temperatur akan didapat selisih berat setelah uji korosi sebagai berikut :

1. Pada temperatur $750^{\circ} \mathrm{C}$ didapatkan $\Delta \mathrm{W}$ sebesar 0,478

2. Pada temperatur $850^{\circ} \mathrm{C}$ didapatkan $\Delta \mathrm{W}$ sebesar 0,263

3. Pada temperatur $950^{\circ} \mathrm{C}$ didapatkan $\Delta \mathrm{W}$ sebesar 0,649

Setelah melakukan pengujian bahan uji artensitik steel AISI 431 akan didapatkan hasil sebagai berikut :

Untuk data bahan uji tanpa laku panas :

$\begin{array}{ll}\text { Massa awal } & =19,824 \mathrm{~g} \\ \text { Massa akhir } & =19,478 \mathrm{~g} \\ \text { Massa hilang } & =0,35 \mathrm{~g} \\ \text { Luas permukaan } & =1.954 \mathrm{in}^{2} \\ \text { Massa jenis } & =7,7 \mathrm{~g} / \mathrm{cm}^{3} \\ \text { Waktu pengkorosian } & =24 \mathrm{jam}\end{array}$

$$
M P Y=\frac{22.272 W l}{D \cdot A \cdot T}
$$

dengan :

$W l$ : Weight Loss (g)

$D$ : Density material

$A$ : Luas penampang korosif $\left(\mathrm{in}^{2}\right)$

$T$ : Waktu pengkorosian min 24 jam (day)

Maka didapatkan hasil laju korosi sebesar 0,518 mpy.

Untuk mengetahui pengaruh variasi temperature terhadap laju korosi baja martensit AISI 431, maka dibuat grafik pada Gambar 10(a). Grafik tersebut menerangkan bahwa benda uji kesatu (awal) adalah baja tahan karat martensit AISI 431 yang dilaku panas pada temperatur $750^{\circ} \mathrm{C}$ dengan holding time 30 menit. Dari grafik menunjukkan bahwa laju korosi flujktuatif, bagian tengah laju korosi lebih tinggi dari pada bagian yang lain dan bagian ujung laju korosinya lebih rendah dari pada bagian yang lain. Selisih laju korosi dengan bagian pangkal besarnya 17 mpy.

Berdasarkan grafik Gambar 10(b), grafik tersebut menerangkan bahwa benda uji kedua adalah baja tahan karat martensit AISI 431 yang dilaku panas pada temperatur $850^{\circ} \mathrm{C}$ dengan holding time 30 menit. Dari grafik menunjukkan bahwa laju korosi fluktuatif, bagian tengah laju korosi lebih tinggi daripada bagian yang lain tetapi perbedaannya pada benda uji 2 ini bagian pangkal laju korosi nya lebih rendah daripada bagian yang lain. Selisih laju krosi dengan bagian ujung besarnya adalah 16 mpy.

Pada grafik Gambar 10(c) menerangkan bahwa benda uji ketiga adalah baja tahan karat martensit AISI 431 yang dilaku panas pada temperatur $950^{\circ} \mathrm{C}$ dengan holding time 30 menit. Dari grafik menunjukkan bahwa daerah yang dekat dengan quenching laju korosi lebih besar dari pada bagian pangkal atau pada specimen yang ke lima atau terutama daerah uji ke empat.

Grafik Gambar 10(d) merupakan grafik perbandingan antara variasi temperatur terhadap laju korosi. Dari grafik perbandingan tersebut di atas akan dapat terlihat bahwa laju korosi dapat meningkat seiring dengan temperatur yang diberikan pada saat melakukan heat treatment pada baja tahan karat martensitik. Disebabkan kandungan krom yang terdapat pada baja tahan karat martensitik tersebut banyak yang tersisip ke dalam butir kristal sedangkan pada batas butir terjadi kekosongan kadar krom sehingga daerah ini awalnya terjadinya korosi pada baja tahan karat martensitik.

Dari hasil ketiga proses laku panas dengan variasi temperatur yaitu $750^{\circ} \mathrm{C}, 850^{\circ} \mathrm{C}, 950^{\circ} \mathrm{C}$, dan holding time 30 menit pada baja martensitik AISI 431 telah jelas bahwa pada temperatur 950C akan mengalami laju korosi yang paling tinggi dari pada temperatur yang lain.

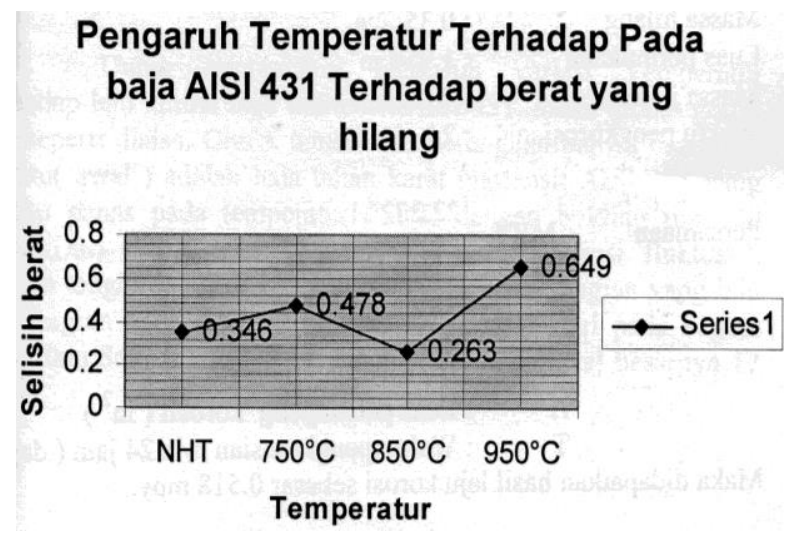

Gambar 9. Nilai Temperatur terhadap massa yang hilang

\section{Analisis Pembahasan Terjadinya Korosi pada Variasi Temperatur}




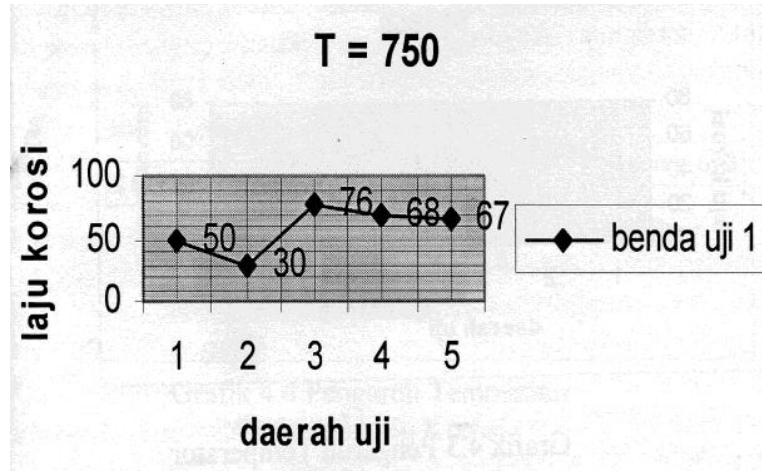

(a)

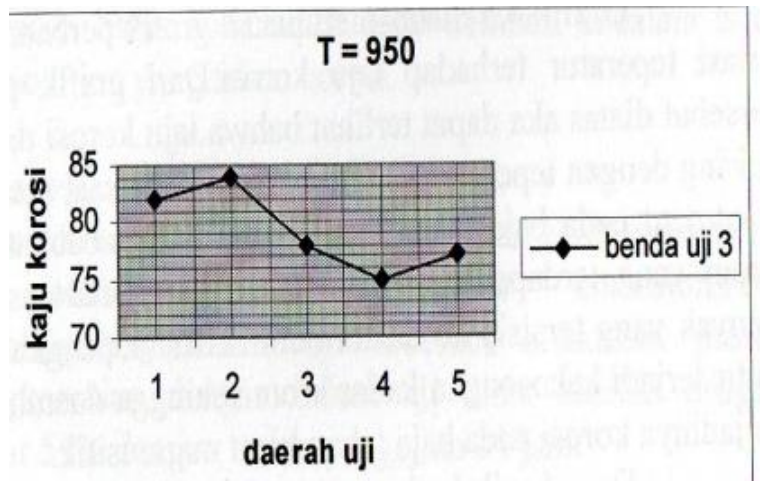

(c)

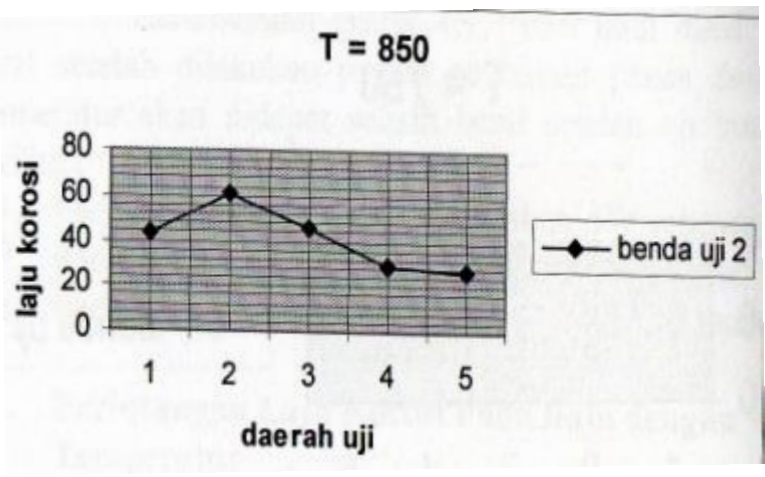

(b)

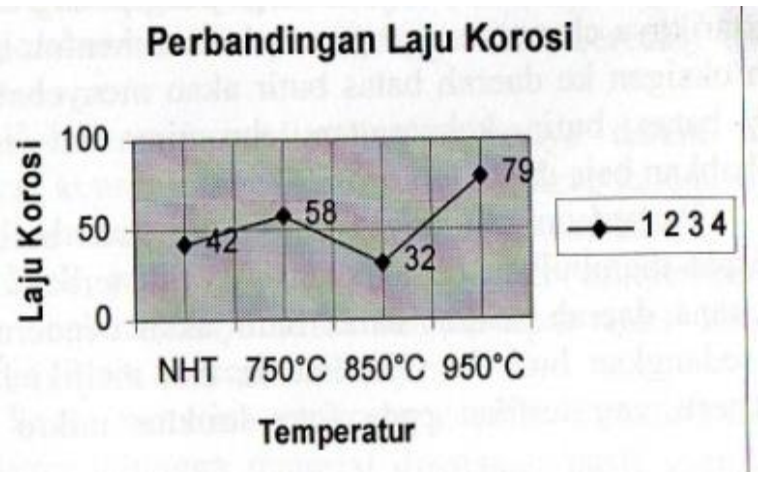

(d)

Gambar 10. Pengaruh temperatur terhadap laju korosi, (a) $\mathrm{T}=750^{\circ} \mathrm{C}$, (b) $\mathrm{T}=850^{\circ} \mathrm{C}$, (c) $\mathrm{T}=950^{\circ} \mathrm{C}$ dan (d) perbandingan laju korosi

Kenaikan laju korosi tersebut dikarenakan semakin naiknya temperatur dikarenakan semakin naiknya temperatur akan menyebabkan chromium berpresipitasi dengan karbon di daerah batas butir sebab daerah batas butir adalah yang mempunyai energi yang paling tinggi.

Akibat dari tertariknya chromium yang semula membentuk lapisan pasif dengan oksigen ke daerah batas butir akan menyebabkan daerah sekitar bats butir kekurangan chromium. Hal inilah yang menyebabkan baja dapat terkorosi.

Perbedaan kandungan chromium pada butir dan batas butir dapat menimbulkan beda potensial yaitu terbentuknya suatu cell dimana daerah sekitar batas butir akan cenderung bersifat anoda. Sedangkan butir bersifat katoda dan memiliki luasan yang besar seperti yang terlihat pada foto struktur mikro setelah uji korosi.

Namun pada temperatur 900C yaitu temperatur di luar batas sensitisasi akan menyebabkan sejumlah besar karbon akan terlarut dan dengan pemberian holding time yang cukup akan memberikan kepada atom chrom yang mengendap pada batas butir untuk larut kembali kedalam butir membentuk solution yang tahan korosi.

\section{Jenis Korosi}

1. Jenis korosi yang menyerang baja tahan karat martensitik ini adalah jenis intergranular corrosion. Foto metallography benda uji sebelum dilakukan proses pengkorosian dengan bahan uji asam klorida dengan kadar 55\% dengan waktu pengujian 24 jam.

2. Jenis korosi yang menyerang baja tahan karat martensitik AISI 431 adalah stress corrosion cracking yang pendinginan yang menggunakan model jominy test disebabkan adanya internal stress akibat perbedaan temperatur yang tinggi.

Adanya perbedaan energi antara anoda dan katoda anoda berada pada batas butir yang besar dan fluktuatif sehingga memudahkan bereaksi dengan lingkungan. Batas butir adalah tempat berkumpulnya impurities dan bahan pembentuk lainnya sehingga akan bereaksi terhadap logam.

Kosentrasi media lingkungannya dalam hal ini adalah tingkat konsentrasi oksigen atau oxidizer karena oksigen akan bersenyawa dengan logam menjadi ferro oksida.

Efek temperatur semakin besar temperatur yang berada pada lingkungannya akan mempercepat reaksi kimia dari tinjauan kimia listrik. (secara umum).

Suatu material mempunyai sifat karakteristik yang berbeda-beda sehingga material dikatakan pasif apabila nilai potensial tinggi sedangkan material yang bersifat aktif nilai potensialnya lebih rendah dan memudahkan material tersebut bereaksi dengan lingkungan sekitar.

Terjadinya reaksi oksidasi dan reduksi antara material dan lingkungan jika ditinjau dari 
diagram phase baja tahan karat martensitik dengan kadar karbon $0,2 \%$ ketika baja tahan karat martensitik AISI 431 ini dipanaskan mencapai temperatur $750^{\circ} \mathrm{C}$ pada temperatur sekitar $500^{\circ} \mathrm{C}$ dan $700^{\circ} \mathrm{C}$ dan belum bertransformasi penuh menjadi austenit sehingga transformasinya hanya berupa ferrit austenit dan prestisipat karbida krom dan diberikan waktu penahanan terbentuknya prestisipasi karbida korom meningkat seiring dengan waktu penahanan yang diberikan.

Laju pendinginan setelah dilakukan variasi temperatur baja tahan karat martensitik AISI 431 didinginkan dengan media air model pendinginannya menggunakan pendinginan jominy test pada saat pendinginan ini baja melewati temperatur sensitivitas kembali sehingga terjadi prestisipasi karbida krom untuk kedua kalinya.

Laju pendinginan dengan model pendinginan jominy dapat mengakibatkan :

1. Merusak lapisan pelindung yang berada pada permukaan baja tahan karat.

2. Terjadinya retak pada batas butir akibat perbedaan temoeratur yang menimbulkan internal stress.

3. Media pendinginan yang berupa air yang dapat menimbulkan korosi.

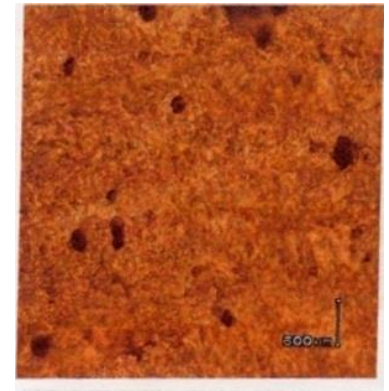

Specimen 1

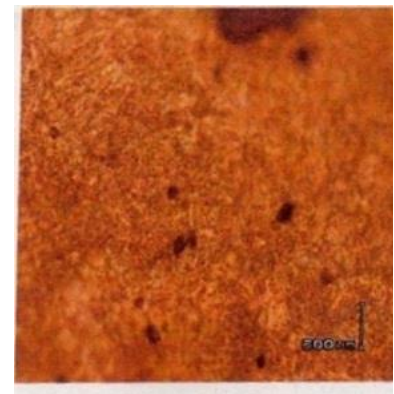

Specimen 2
Gambar 11. Hasil struktur mikro pada benda uji sesudah korosi (temperatur $950^{\circ} \mathrm{C}$, holding time 30 menit \& perbesaran 500 kali) dan direndam menggunakan $\mathrm{HCl}$ selama 24 jam

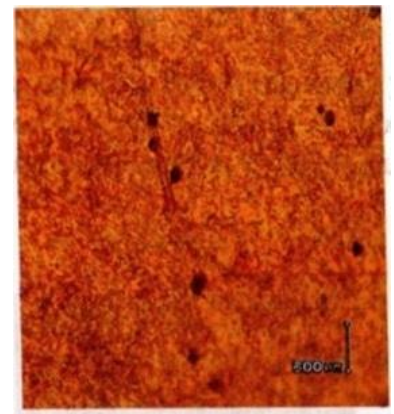

Specimen 1

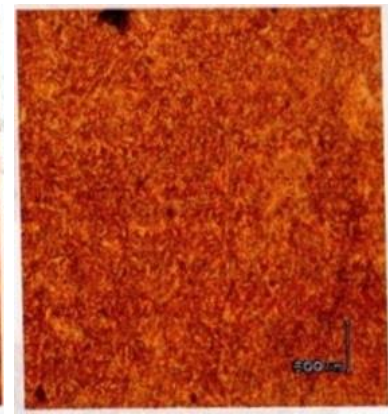

Specimen 2
Gambar 12. Hasil struktur mikro pada benda uji sesudah korosi (temperatur $750^{\circ} \mathrm{C}$, holding time 30 menit \& perbesaran 500 kali) dan direndam menggunakan $\mathrm{HCl}$ selama 24 jam

Pengujian dengan media korosif guna perhitungan laju korosi dengan $\mathrm{HCl}$
1. Mengumpulnya prestisipasi karbida krom pada daerah batas butir saat laku panas holding time dan laju pendinginan membuat batas butir mengalami kekosongan unsur krom sehingga daerah batas butir mudah untuk bereaksi dengan lingkungan sekitar.

2. Pada saat pendinginanbenda uji mengalami internal stress kemudia terjadi retak pada batas butir disebabkan perbedaan temperatur pada saat pendinginan.

3. Perendaan benda uji dengan menggunakan media korosif sifatnya hanya mempercepat laju korosinya.

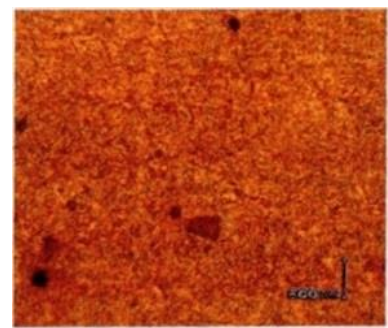

Specimen 3

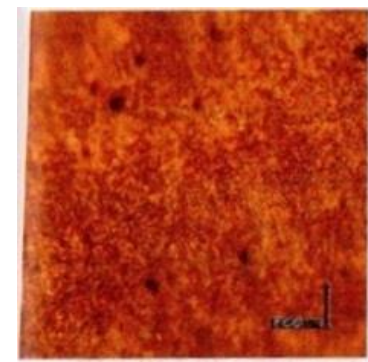

Specimen 4

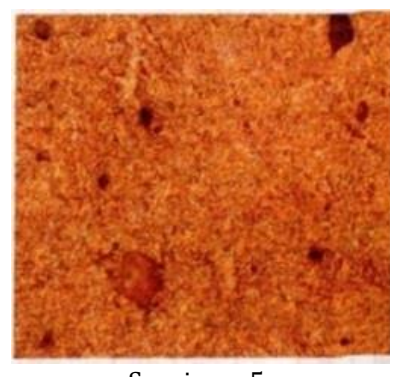

Specimen 5
Gambar 13. Hasil struktur mikro pada benda uji sesudah korosi (temperatur $950^{\circ} \mathrm{C}$, holding time 30 menit \& perbesaran 500 kali) dan direndam menggunakan $\mathrm{HCl}$ selama 24 jam

\section{PENUTUP}

Kesimpulan setelah melakukan analisis dan pembahasan terhadap pengujian baja tahan karat martensitik AISI 431 adalah 1) jenis korosi yang terjadi pada baja tahan karat martensitik AISI 431 adalah korosi intergranular, 2) pemberian temperatur yang tinggi dapat menyebabkan laju korosi semakin meningkat pada baja tahan karat martensitik AISI 431 dan 3) laju korosi yang terbesar pada temperatur $950^{\circ} \mathrm{C}$ dengan holding time 30 menit dengan laju korosi 76 mpy.

Adanya penelitian lebih lanjut tentang sifat mekanis pada baja tahan karat martensitik steel dikarenakan dari data disebutkan bahwa baja baja tahan karat martensitik steel dapat meningkat kekuatannya. 


\section{DAFTAR PUSTAKA}

Fontana, M. G. (2005). Corrosion engineering. Tata McGraw-Hill Education.

Schweitzer, P. A. (1987). What every engineer should know about corrosion. CRC Press.

Sendriks, A. J. (1979). Corrosion of Stainless Steels. New York. John Willey and Sons. INC.
Suherman, W. (2003). Ilmu Logam. Jurusan Teknik Mesin, Institut Teknologi Sepuluh Nopember Surabaya..

Supomo, Heri. (2003). Korosi Teknik Perkapalan Surabaya. Fakultas Teknologi Kapal ITS.

Williams Jr, D. C. (2000). Materials science and engineering: an introduction.John Willey: USA, 17-235. 
E Gunawan, dkk / Teknika, Vol. 1, No.1, Juni 2017, 55-66

Halaman ini sengaja dikosongkan 